\title{
Christelle Jullien, « La piété du Perse "barbare". Modélisations chrétiennes en milieu sassanide »
}

\section{Marie-Joseph Pierre}

\section{(2) OpenEdition \\ 12 Journals}

\section{Édition électronique}

URL : http://journals.openedition.org/abstractairanica/50968

DOI : 10.4000/abstractairanica.50968

ISBN : 1961-960X

ISSN : 1961-960X

Éditeur :

CNRS (UMR 7528 Mondes iraniens et indiens), Éditions de l'IFRI

Référence électronique

Marie-Joseph Pierre, " Christelle Jullien, «La piété du Perse "barbare". Modélisations chrétiennes en milieu sassanide » », Abstracta Iranica [En ligne], Volume 40-41 | 2019, document 20, mis en ligne le 30 décembre 2019, consulté le 26 avril 2021. URL : http://journals.openedition.org/abstractairanica/ 50968 ; DOI : https://doi.org/10.4000/abstractairanica.50968

Ce document a été généré automatiquement le 26 avril 2021

Tous droits réservés 


\title{
Christelle Jullien, « La piété du Perse "barbare". Modélisations chrétiennes en milieu sassanide »
}

\author{
Marie-Joseph Pierre
}

\section{RÉFÉRENCE}

Christelle Jullien, « La piété du Perse "barbare". Modélisations chrétiennes en milieu sassanide » in F. Jullien (éd.). Guerre et paix en monde iranien. Revisiter les lieux de rencontre. (Studia Iranica. Cahier 62), Paris/Louvain: AAEI/Peeters, 2018, p. 65-88

Dans cette étude, l'A. analyse les modalités d'écriture conduisant les écrivains syriaques à présenter une image du roi perse sassanide oscillant entre réprobation et admiration. Cette perception aboutit à une représentation refaçonnée voire idéalisée en fonction d'impératifs culturels et de modélisations traditionnelles. La condamnation du Perse, considéré par le regard de l'“autre" byzantin comme un "barbare", revient en fait à réprouver la religion officielle de l'empire sassanide, le mazdéisme, considérée comme une forme de paganisme. Dans cette perspective, les descriptions tout à fait originales de la littérature hagiographique et historiographique ont permis aux communautés chrétiennes périodiquement soumises à discrimination de transposer leurs espérances sur le souverain. 


\section{AUTEURS}

\section{MARIE-JOSEPH PIERRE}

Directrice d'Études honoraire, EPHE 